ARTICLE HISTORY: Received: September 18, 2021 Accepted: November 12, 2021 Published: November 19, 2021

ОРГАНИЗАЦИЯ НАЛОГОВОГО КОНТРОЛЯ В РОССИЙСКОЙ ФЕДЕРАЦИИ

\author{
Царбаева Альбина Булатовна \\ Студент - магистрант 3 курса группы 01ЮРв 7910 \\ Московский финансово-юридический университет МФЮА
}

\title{
ORGANIZATION OF TAX CONTROL IN THE RUSSIAN FEDERATION
}

\author{
Tsarbaeva Albina Bulatovna \\ Student - undergraduate of the 3rd year of group 01YURv7910 \\ Moscow University of Finance and Law MFLA
}

\begin{abstract}
Аннотация. В статье рассматриваются принципы построения налоговой системы, содержание налоговой политики, характеризуется налогообложение в современной России. А так же формы проведения налогового контроля в Российской Федерации и уклонение от уплаты налогов. Анализируются актуальные вопросы нормотворческой деятельности в указанной сфере.

Abstract. The article discusses the principles of building a tax system, the content of tax policy, characterizes taxation in modern Russia. As well as the forms of tax control in the Russian Federation and tax evasion. Topical issues of rule-making activity in this area are analyzed.

Ключевые слова: налог, НК РФ, ФНС, налоговый контроль, формы, налоговое преступление, УК РФ.

Key words: tax, Tax Code of the Russian Federation, FTS, tax control, forms, tax crime, Criminal Code of the Russian Federation.
\end{abstract}

Действующая в Российской Федерации система налогов и сборов строится в соответствии с государственным устройством и сформировалась с принятием в 1998 г. первой части Налогового кодекса

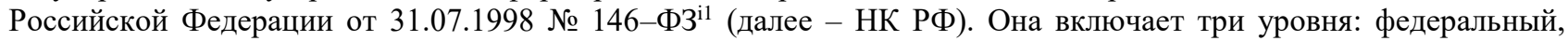
региональный и местный. Система налогов и сборов в Российской Федерации отражает федеративное устройство Российского государства и представлена тремя условиями. В настоящее время в систему налогов и сборов входит 8 федеральных налогов и сборов, 3 региональных налога и 3 местных налога и сбора.

Контроль за правильностью исчисления, полнотой и своевременностью внесения налогов в бюджетную систему осуществляет Федеральная налоговая служба (ФНС) РФ, деятельность которой координирует Министерство финансов Р $\Phi^{2}$.

В целях проведения налогового контроля организации и физические лица подлежат постановке на учет в налоговых органах соответственно по месту нахождения организации, месту нахождения ее обособленных подразделений, месту жительства физического лица, а также по месту нахождения принадлежащего им недвижимого имущества и транспортных средств и по иным основаниям, предусмотренным НК РФ.

Действующий Уголовный Кодекс РФ (далее УК РФ) содержит целый ряд статей, предусматривающих уголовную ответственность за совершение уклонения от уплаты налогов и сборов, которые объединяют единым понятием «налоговые преступления». Все указанные статьи расположены в главе «Преступления в сфере экономической деятельности» раздела УК РФ «Преступления в сфере экономики».

Так, неуплата налогов каралась в дореволюционной России достаточно суровыми наказаниями, предусматривающими как штрафы и конфискацию имущества, так и телесные наказание и смертную казнь в отношении должностных лиц. После революции 1917 года, когда была отменена частная собственность и отсутствовала мотивация уклонения от уплаты налогов, исчезли и налоговые составы преступления. Принятый в 1960 году Уголовный кодекс РСФСР содержал единственную статью, которая предусматривала ответственность за неуплату налогов в военное время.

Наиболее распространёнными с точки зрения практического применения из приведённого перечня налоговых преступлений являются статья 198 УК РФ 3 и статья 199 УК РФ, предусматривающие ответственность за уклонение от уплаты налогов соответственно физических лиц и организаций. Эти две статьи

${ }^{1}$ Налоговый кодекс Российской Федерации (часть первая) от 31.07.1998 № 146-ФЗ (ред. от 02.07.2021) // Собрание законодательства РФ. 03.08.1998. № 31. Ст. 3824.

2 Положение о ФНС утвержденное Постановлением Правительства РФ от 30.09 .2004 № 506 (в ред. от 03.07.2014).

${ }^{3}$ Уголовный кодекс Российской Федерации" от 13.06.1996 N 63-Ф3 (ред. от 01.07.2021) (с изм. и доп., вступ. в силу с 22.08.2021) 
являются исторически самыми старыми налоговыми статьями, введёнными в действие в современной России. Все налоговые преступления объединяет их родовой и видовой объекты. Родовым объектом налоговых преступлений являются отношения в сфере экономической деятельности, а видовым объектом - отношения в сфере исчисления и уплаты налогов. Устанавливая уголовную ответственность за совершение, налоговые преступления государство помимо общих целей уголовного законодательства (охрана общественных отношений и предупреждение совершения новых преступлений), преследует ещё одну, фискальную цель, которая российским уголовным правом официально не признаётся. Цель эта заключается в необходимости пополнения бюджета за счёт налоговых отчислений, что опосредованно определено через специальное основание освобождения о совершения налоговых преступлений, сформулированном в Примечании к статье 199 УК РФ и ст. 76.1 УК РФ.

\section{Список литературы}

1. Мигачев Ю. И., Попов Л. Л. Административное право: учебник. Норма, 2019. 224 с.

2. Мигачев Ю. И., Попов Л. Л., Тихомиров С. В. Административное право Российской Федерации / под ред. Л. Л. Попова. М.: Юрайт, 2018. 447 с.

3.Налоги и налогообложение: учебник для бакалавров/под ред. Д.Г. Черника. - М.: Юрайт, 2013. -393 c.

4. Пансков В.Г. Налоги и налогообложение: теория и практика: учебник для бакалавров - М.: Юрайт, 2012. -680 c.

5. Федеральная налоговая служба. Доклад о результатах и основных направлениях деятельности на 20142017 годы. http://www.nalog.ru/rn77/related_activities/statistics_and_analytics/effectiveness/.

6. Аналитическая справка «О поступлении администрируемых ФНС России доходов в консолидированный бюджет Российской Федерации в 2013 году» http://analytic.nalog.ru/portal/index.ru-RU. htm.

\section{Refrences}

1. Migachev YU. I., Popov L. L. Administrativnoye pravo: uchebnik. Norma, 2019. 224 p.

2. Migachev YU. I., Popov L. L., Tikhomirov S. V. Administrativnoye pravo Rossiyskoy Federatsii /ed. L. L. Popova. M.: Yurayt, 2018. 447 p.

3. Nalogi i nalogooblozheniye: uchebnik dlya bakalavrov/ed. D.G. Chernika. - M.: Yurayt, 2013. -393 p.

4. Panskov V.G. Nalogi i nalogooblozheniye: teoriya i praktika: uchebnik dlya bakalavrov - M.: Yurayt, 2012. $680 \mathrm{p}$.

5. The Federal Tax Service. Results and milestones report 2014-17. http://www.nalog.ru/rn77/related_activities/statistics_and_analytics/effectiveness/.

6. Analytical note "On the receipt of incomes administered by the Federal Tax Service of Russia to the consolidated budget of the Russian Federation in 2013" http://analytic.nalog.ru/portal/index.ru-RU. htm. 